\title{
Avrupa Birliği Uygulamaları Çerçevesinde Türkiye için İstihdam Odaklı Asgari Gelir Desteği Arayışları
}

İLKNUR KARAASLAN*

ilknurkaraaslan@yahoo.co.uk

Özet: Küreselleşme süreciyle birlikte yaşanan ekonomik krizler, yoksulluk, işsizlik, sosyal dışlanma gibi sorunların artmasına yol açmıştır. Yaşanan ağır sosyo-ekonomik koşullar sosyal güvenlik sistemlerinin de köklü bir kriz yaşamasına yol açmakta ve çözüm için başvurulan yöntemlerden biri de "asgari gelir desteği" olmaktadır. AB ülkelerindeki asgari gelir desteği uygulamalarına bakıldiğında hem eski olması ve hem de geniş kapsaml olması itibariyle ülkemize örnek teşkil edebileceği dü̧̈ünülmektedir. Diğer taraftan, AB ülkelerinin sosyal yardım alanına ödenek ayırmakta zorlandığı ve bu sebeple özellikle 2000'li yılların başından itibaren $A B$ ülkelerinde aktivasyon (sosyal yardım faydalanıcılarını istihdama yönelten faaliyetler) konularına önem verildiği görülmektedir.

Türkiyede "asgari gelir desteği" uygulaması mevcut olmayıp "benzeri" uygulamalardan söz etmek mümkündür. Diğer taraftan AB uygulamalarında olduğu gibi Türkiye'de de sosyal transferlerin ve özelde "asgari bir gelir" takviyesinin yoksulluğu azaltmada etkili olabileceği ve verilecek bir asgari gelir desteğinin AB uygulamalarma benzer şekilde aktivasyon koşullu olması gerektiği düşünülmektedir.

Anahtar kelimeler: Asgari gelir desteği, Avrupa Birliği, istihdam

\section{Giriş}

21. yüzyılın başından itibaren etkisini iyice gösteren "küreselleşme" ile birlikte dünyada ekonomik, sosyal, kültürel unsurlar başta olmak üzere hemen her alanda büyük bir değişim/ dönüşüm süregelmektedir. Bu değişimle bir arada gerçekleşen teknolojik gelişmeler ve yenilikler ekonomik verimliliği büyük ölçüde arttırmış ve bu artışın aynı zamanda refah seviyesini de arttırması beklenmiştir. Bununla birlikte pratikte durum böyle olmamıştır. Aksine dünyada ciddi oranda bir yoksulluk söz konusudur ve ülkeler çok çeşitli ekonomik, toplumsal ve siyasal sorunlarla karşı karşıyadır. Bütün bu gelişmeler ülkelerin ekonomik ve sosyal yapılarında bir dizi değişikliğin ortaya çıkmasına neden olmuştur; sıkça yaşanan ulusal ve küresel ekonomik krizler, sürekli yüksek işsizlik, yüksek seviyede kamu borçları, istihdama yol açmayan ekonomik büyüme vb. oluşumlar bu sorunlardan bazılarıdır. Bu sorunların çalışma hayatına yansımaları ise istihdam güvencesizliği, esnek çalışma/ücretler, sosyal güvenlik ağının olmayışı, sosyal eşitlik ve sosyal adalet ile ilgili sorunlar ve benzeri konulardır. $\mathrm{Bu}$ anlamda dünyanın her yerinde istihdam edilen veya edilmeyen birçok kişi için büyük bir gelecek endişesi ve güvensizlik bulunmaktadır.

Diğer taraftan, bu gelişmeler refah devletini de erozyona uğratmış ve refah devletinin sosyal güvenlik, sosyal adalet, sosyal barış gibi kavramları gözden geçirmek suretiyle yeniden yapılanması gündeme gelmiştir. Refah toplumlarında tam istihdamın güçleşmesi, bulunan işlerin

\footnotetext{
* Dr., Çalışma Ekonomisi ve Endüstri İlişkileri Anabilim Dalı.
} 
çoğu zaman düzensiz, yarı zamanlı ve yoksulluk sınırını aşacak miktarda gelir getirmeyen işler olması, kadınların iş hayatında artan rolü ve klasik aile yapısının çözülmeye başlaması gibi değişimler bu dönemin önemli özelliklerindendir. Bununla birlikte, söz konusu süreç yoksulluk ve sosyal dışlanma sorunlarını da beraberinde getirmiştir. Sonuç olarak yoksul ve dezavantajlı grupların içinde bulundukları çıkmazdan kurtulmaları için çareler aranmaya başlanmıştır. Bu koşullar altında "asgari gelir desteği sistemleri” refah devletlerinin son çare uygulamalarından biri olarak ön plana çıkmaktadır. Asgari gelir desteği, yoksulluk sınırının altında kalan kişilere devlet tarafından hiçbir şart aranmaksızın sağlanan bir sosyal yardım türüdür; daha önce çalışmış ve pirim ödemiş olmak veya herhangi bir özel statüye (kategorik yardımlar) sahip olmak gibi şartlar aranmamaktadır.

Sosyo-ekonomik sorunlara bir çözüm olarak ileri sürülen “asgari gelir desteği”nin toplumdaki yoksulluk ve gelir dağılımı bozukluğunu düzeltmede tek başına yeterli olması beklenmemelidir. Diğer taraftan özellikle başlangıçta ciddi miktarda bir kamu kaynağına ihtiyaç duyulacağından sistemin sağlıklı bir biçimde işlemesi büyük ölçüde adil ve güçlü bir vergi sisteminin varlı̆̆ına ve kayıtdışılığın ortadan kaldırılmasına bağlıdır. Ayrıca küreselleşme ve uluslararası rekabet ile ulus devletlerin gücünün iyice zayıflamış olması sosyal yardım alanında ödenek ayırmayı zorlaştırmaktadır ve devletlerin söz konusu "asgari gelir desteği" yardımlarını uzun vadeli olarak sürdürmeleri güçleşmektedir.

Tüm bu gerekçelerle özellikle 1990'lı yıllardan itibaren asgari gelir desteğinin aktivitelere katılım şartı ile verilmesi gündeme gelmiştir. Bu aktivitelerin teorik olarak istihdama öncülük etmesi beklenmektedir. OECD (Ekonomik Kalkınma ve İşbirliği Örgütü) ve AB (Avrupa Birliği)'nin önerileri de bu doğrultudadır. OECD direkt nakit desteği yardımlarının işe geri dönmeyi teşvik etmek üzere dizayn edilen tedbirlerle ikame edilmesini önermektedir. Avrupa Parlamentosu ise toplumdaki yoksul ve muhtaç durumda bulunan tüm çocuk, yetişkin ve yaşlıların asgari bir geçim seviyesini sağlayacak düzeyde bir yaşam standardına kavuşturulmaları için asgari gelir planlarından etkili bir şekilde faydalanılması ve dezavantajlı gruplar için de kendilerine uygun olan ve süreklilik arz eden işler yaratılmasının önemine vurgu yapmaktadır. Parlamento, bu fikrin bir yansıması olarak refah politikası ile aktif iş piyasası politikasının paralel bir biçimde yönetilmesi gerektiği görüşüne sahiptir.

Son yıllarda yoksullukla mücadele kapsamında ülkemizde gerek kurumsal alt yapının iyileştirilmesinde gerekse dezavantajlı gruplara ayrılan kaynakların artırılmasında önemli ilerlemeler kaydedilmiştir. Bu kapsamda, sosyal yardımların daha etkin olarak uygulanması bağlamında pek çok Batı ülkesinde uygulanan asgari gelir desteğinin ülkemizde de uygulanabilirliği farklı düzlemlerde tartışılmaktadır. ${ }^{1}$ Ülkemizde asgari gelir desteğine benzer bazı uygulamalar mevcut olup şartlı nakit transferleri, 2022 Sayılı Kanun gereği yaşlılara ve özürlülere yapılan yardımlar bunlardan birkaçıdır. Makalenin ilerleyen bölümlerinde bu konuda detaylı bilgi sunulacaktır. Ayrıca ASPB ve İş-Kur'un ortaklaşa yürüttüğü çalışmalar neticesinde sosyal yardımlarla istihdam arasında bir bağ kurulmaya çalışılmaktadır. Söz konusu bağ Avrupa ülkelerinin bazılarında büyük ölçüde sağlanmış olup örneğin çok detaylı ve geniş bir sosyal yardım sistemine sahip olan Fransa'da asgari gelir desteği yardımı neredeyse bir iş arama/bulma desteğine dönüşmüştür. Bu itibarla Avrupa örneğinde olduğu gibi Türkiye'de de sosyal yardım alan kişiler içerisinde çalışma yeteneğine sahip olanların bir an önce emek piyasasına yönlendirilmesini sağlamak sosyal yardım-istihdam ilişkisini bu dü-

\footnotetext{
${ }^{1}$ Selim Coşkun, Samet Güneş ve Fatih Ortakaya, "Asgari Gelir Desteği ve Türkiye’de Uygulanabilirliği: Bir Model Denemesi," Gazi Üniversitesi İ.I. B.F. Dergisi, 13/3, 2011, s. 131.
} 
şünceye uygun bir biçimde kurgulamak gerekmektedir.

Yoksulluk ve işsizliğin hem Avrupa hem de Türkiye için önemli bir sosyal ve ekonomik sorun olması çözüm için yeni arayışları gündeme getirmektedir. Bu çerçevede asgari gelir desteği konusu daha sık gündeme gelmekte, istihdam odaklılık konusu ise ayrıca vurgulanmaktadır.

\section{Avrupa Birliği'nde Asgari Gelir Desteğinin Belirgin Özellikleri}

Dünyada asgari gelir desteği konusunda en kapsamlı ve gelişmiş örnekler AB ülkelerinde mevcuttur. Birçok AB ülkesinde asgari gelir desteği uygulamasının bir türü/şekli "son çare uygulaması" olarak uygulanmaktadır. Bu asgari gelir desteği uygulamalarının ortak bir amacı yeterli kaynaklara sahip olmayan ailelere ve bireylere asgari bir yaşam standardını garanti etmektir. ${ }^{2}$ Bununla birlikte söz konusu uygulamalar kapsayıcılık ve yeterlilik konularında olduğu kadar yoksullukla mücadele ve sosyal dışlanma konularında da birbirlerinden çok büyük farklılıklar göstermektedirler. ${ }^{3}$

$\mathrm{AB}$ üyesi ülkeler arasında sosyal koruma hakkında sürekli bir bilgi alışverişini sağlamak üzere kurulan MISSOC (Mutual Information System on Social Protection - Sosyal Korumada Ortak Bilgi Sistemi) 1990 yılından beri faaliyet göstermektedir, asgari gelir desteği konusunda MISSOC verilerine sıklıkla başvurulmaktadır. AB ülkeleri asgari gelir desteği’nin uygulanış biçimi açısından temel olarak üç grupta incelenebilir;

Birinci tür ülkelerde asgari gelir, "genele hitap eden", "kuşatıcı" bir biçimde algılanmaktadır: asgari gelir, mevcut olan tek (ya da en önemli) gelir desteğidir ve bu gelir desteği yeterli kaynakları olmayan herkes için söz konusudur, sadece toplumdaki belli hedef gruplarla sınırlı değildir. Bu tip uygulama Lüksemburg, Avusturya, Polonya, Malta, Slovak Cumhuriyeti ve Romanya için söz konusudur.

Karşı grupta, asgari gelirin bir son çare uygulaması olarak dizayn edildiği ülkeler mevcuttur. Bu ülkelerde kişiler diğer çözüm yollarının tümünü tüketmişlerdir ve son çare olarak asgari gelir desteği yardımı için başvurmuşlardır. Söz konusu ülkeler hem kategorik yardım planları hem de genel bir asgari gelir uygulaması sunmaktadırlar. Asgari gelir, toplumun belli gruplarına asgari geliri (yaşlı, engelli ve işsiz gibi) ayrı şekillerde garantileyen sistemler içerisinde bir son çare uygulamasıdır. Bu kategorik yardımların amacı yetersiz kaynaklara sahip bulunan sosyal gruplar için daha belirgin güvenlik ağları sağlamaktır. Özellikle Fransa, Finlandiya, Almanya, İrlanda ve Birleşik Krallık bu grup içerisinde yer almaktadır. ${ }^{4}$

Daha küçük bir grup oluşturan ülkelerde ise kategorik planlar mevcut olmakla birlikte genel son çare tedbirleri yoktur (İtalya, Macaristan ve Yunanistan) veya ulusal bir asgari gelir planı mevcut değildir (İspanya). Diğer ülkeler ise bu üç grup içerisinde bir pozisyonda yer almaktadır. Belçika, Hollanda, İsveç ve Çek Cumhuriyeti’nde asgari gelir desteği "kuşatıcı" bir tedbirdir. Bulgaristan, Kıbrıs, Danimarka, Estonya, Letonya, Litvanya, Slovenya ve Portekiz’de ise daha çok bir "son çare" uygulaması olarak görülmektedir. ${ }^{5}$

\footnotetext{
${ }^{2}$ Coşkun, Güneş ve Ortakaya, a.g.m., s. 134.

${ }^{3}$ Chiara Crepaldi, Claudio Castegnaro, Sandra Naaf ve Daniela Mesini, "The Role of Minimum Income for Social Inclusion in the European Union 2007-2010", Report Made for European Parliament, Milan, 2010, s. 1.

${ }^{4}$ Ayşe Buğra, Çağlar Keyder, Ilgın Erdem, Sosyal Yardım Uygulamaları ve Topluma Yararlı Faaliyet Karşıllğında Asgari Gelir Desteği Uygulaması, Ankara: UNDP, 2006, (Çevrimiçi) http://www.undp.org.tr/publications Documents/socialassistancereports.pdf (02.01.2012), s. 32.

${ }^{5}$ Crepaldi vd., a.g.e., s. 32 .
} 
Tablo.1: Asgari Gelir Desteği Uygulamasının Karakteristik Özellikleri

\begin{tabular}{|c|c|c|c|c|}
\hline $\begin{array}{l}\text { Asgari Gelir } \\
\text { Desteğinin } \\
\text { “Kuşatıcı" Bir } \\
\text { Uygulama } \\
\text { Olduğu Ülkeler }\end{array}$ & $\&$ & $\$$ & $\begin{array}{l}\text { Asgari Gelir } \\
\text { Desteğinin } \\
\text { "Son Çare } \\
\text { Uygulaması" } \\
\text { Olduğu Ülkeler }\end{array}$ & $\begin{array}{l}\text { Kategorik } \\
\text { Uygulamalar } \\
\text { ve/veya Ulusal } \\
\text { Bir Asgari } \\
\text { Gelir Desteği } \\
\text { Uygulamasının } \\
\text { Olmadığı Ülkeler }\end{array}$ \\
\hline Avustralya & Belçika & Bulgaristan & Finlandiya & İtalya \\
\hline Lüksemburg & Hollanda & G. Kibris & Fransa & Macaristan \\
\hline Malta & İsveç & Danimarka & Almanya & Yunanistan \\
\hline $\begin{array}{l}\text { Slovak } \\
\text { Cumhuriyeti }\end{array}$ & Çek Cumhuriyeti & Estonya & İrlanda & İspanya \\
\hline & & Letonya & İngiltere & \\
\hline & & Litvanya & & \\
\hline & & Slovenya & & \\
\hline & & Portekiz & & \\
\hline
\end{tabular}

Kaynak: Crepaldi vd., s. 33; Buğra, Keyder ve Erdem, a.g.e., s. 33.

AB’ye üye ülkelerin neredeyse tamamı, vatandaşlarını yoksulluktan korumaya yönelik olarak bir asgari gelir programını uygulamaktadır. Yoksullukla mücadele amacını güden mevzuatın geçmişi 1601 tarihli İngiliz Fakirleri Koruma Yasası’na (Poor Law) kadar uzanmaktadır. İkinci Dünya Savaşı'ndan sonra, Danimarka'da Social Bistand (1961), Almanyada Sozialhilfe (1962), Hollanda'da Algemene Bijstand (1963), Belçikada Minimex (1974), Fransa'da Revenue Minimum d'Insertion (RMI) (1988), İspanya'da 1980'lerin sonunda ve 1990'larda uygulanan yasalar, Bask Ülkesi (1988), Katalonya (1990) ve sonra da İspanyảnın diğer bölgelerinde ve Portekiz'de 1997 yılında yürürlüğe giren yasalar AB ülkelerinde uygulanan benzer mevzuatlardır. Asgari gelir programları merkez ve Doğu Avrupa ülkelerinde 1990'lar boyunca, bazı durumlarda DB’nin desteği ile uygulanmaya başlanmıştır. ${ }^{6}$

Tüm Avrupa ülkeleri değişik şekillerde ve zamanlarda evrensel, kalıntı, dağıtımcı olmayan tamamlayıcı planları, tüm yeterli kaynaklar vasıtasıyla "onurlu bir yaşam" veya "temel ihtiyaçların karşılanmasını (sosyal yardım) garanti etmek amacıyla geliştirmişlerdir. Söz konusu planlar, yoksulluğu önlemek ve onurlu bir yaşam standardına ulaşamayan aile ve bireylere bunu sağlamak üzere dizayn edilmişlerdir. Uzun yıllardır sosyal yardım sistemini pratikte yaşamış olan ülkelerde bu planlar ilk önce bir kalıntı tamamlayıcı sosyal koruma olarak algılanmıştır, tam istihdam hedefi gerçekleştiğinde ve zenginlik artıp tüm bireyler daha iyi yaşam şartlarına kavuştuğunda kendiliğinden yok olacağı düşünülmüştür. Fakat son on yıllarda yüksek seviyede işsizliğin ısrarla devam etmesi ve ilgili sosyal politikaların yoksulluğu yok etmekte başarısız olması, yetersiz kalması, tersine bu planların artan bir şekilde ehemmiyete sahip olduğunu ve her zaman gerekli olduğundan çok daha fazla gerekli olduğunu göstermiştir.7

\footnotetext{
${ }^{6}$ EuropeAid, “Asgari Gelir Programları Hakkında Ek Rapor," (Çevrimiçi) http://www.sgk-kap.org/database/ reports/B1_C5_006.pdf(12.01.2012), s. 2.

${ }^{7}$ Ramón Peña Casas, "Minimum Income Standards in Enlarged EU: Guaranteed Minimum Income Schemes" Working Paper II: Setting Minimum Social Standards across Europe, (Çevrimiçi) http://www.eapn.ie/pdfs/155_ paper\%20II\%20-\%20Minimum\%20income\%20standards\%20in\%20enlarged\%20EU.pdf (12.04.2012), s. 17.
} 
AB ülkelerinde "asgari gelir desteği” neredeyse her ülke için farklı bir mana teşkil etmekte ve ona göre de farklı isimlerle nitelendirilmektedir. Örneğin bazı ülkelerde (Fransa, Lüksemburg, İspanya, Portekiz, Letonya) plan isimlendirilmelerinde açık bir biçimde "asgari gelir" ibaresi yer alırken, aynı plan başka ülkelerde (Avusturya, Almanya, Hollanda, Danimarka, İsveç, Çek Cumhuriyeti, Polonya, Slovenya, Malta) "sosyal yardım”, "entegrasyon veya ilave" (Belçika, Portekiz), "kamu yardımı" (Kıbrıs), "gelir desteğiı"(Birleşik Krallık), "tamamlayıc1 refah ödeneği” (İrlanda), "geçim yardımı" (Estonya), "maddi ihtiyaç yardımı" (Slovakya) veya "sosyal yardım" (Litvanya) olarak belirlenmiştir."

Bazı ülkelerde asgari gelir yalnız başına mevcut bulunan bir güvenlik ağıdır, bazı ülkelerde ise garantili asgari gelir diğer ödenekler ve ilgili haklarla birlikte daha geniş bir güvenlik ağının bir parçasıdır. ${ }^{9}$

$\mathrm{Bu}$ terminolojilerin ötesinde garantili gelir planları bazı ortak özelliklere sahiptir;

- "Garantili"dir, "dağıtımcı olmayan”dır (evrensel esaslı olarak verildiğinden, sosyal koruma sigorta sistemlerine önceki katılımlardan bağımsız olduğu için),

- Asgari seviye”dedir (sosyal korumada güvenlik ağının son aşaması olarak düşünüldüklerinden ve ulusal veya yerel asgari yaşam standartları veya ihtiyaçları algısına bağlı olarak şekillendiklerinden),

- Sosyal yardım olarak sübjektif ve isteğe bağlı olmayan bir hakkın ifadesidir (bireyler tarafından talep edilmelidir ve otomatik olarak bağlanmamaktadır),

- Miktarı-seviyesi kanunla ya da idari kurallar tarafından herkes için eşit bir biçimde belirlenmektedir, genellikle gelir testine göre değişen miktarlarda nakit olarak verilmektedir,

- Niteliği ve miktarı bireyin veya hane halkının kaynaklarının belirlenen minimum eşiğini geçmemesi şartına bağlıdır. ${ }^{10}$

Asgari gelir desteği "asgari nakit gelir desteği yardımı" olarak veya bazı ülkelerde ayni yardım (tamamlayıcı) şeklinde (örneğin; gıda, giyim) ve/veya diğer ödenekleri (aile, konut...) ve/veya hizmetleri tamamlayıcı olarak düzenlenmektedir. Garantili asgari gelir, evrensel, dağıtımcı olmayan, sübjektif ve isteğe bağlı olmayan bir sosyal yardım hakkının ifadesidir, genellikle gelir testine bağlı olarak değișen miktarlarda verilmektedir. Asgari gelir planının en önemli işlevleri, diğer sosyal koruma planları tarafından kapsanmayan bireyleri ve aileleri koruması ve kendilerini desteklemekte yetersiz olan kaynaklar ile ciddi bir yoksulluğa düşmelerini önlemesidir. Ayrıca asgari gelir planı, yoksul kişilerin gelişmiş ülkelerde algılanan onurlu yaşam standartlarının altına düşmelerini engellemek için sosyal korumanın son güvenlik ağı olarak da rol oynamaktadır. ${ }^{11}$

Garantili asgari gelir sıklıkla sosyal koruma yardımı olmayan "temel gelir” veya "evrensel gelir" ile karıştırılmaktadır. Temel gelir şu an için teorik bir kavramdır, toplumda herkese, bireyin veya ailenin mevcut kaynaklarından (gelir testi olmayan) ve statüsünden veya sosyo-demografik özelliklerinden bağımsız olarak yapılan bir ödeme olarak tanımlanmaktadır. ${ }^{12}$

\footnotetext{
${ }^{8}$ a.g.e., s. 17.

${ }^{9}$ a.g.e., s. 17-18.

${ }^{10}$ a.g.e., s. 18.

${ }^{11}$ a.g.e., s. 18 .

${ }^{12}$ a.g.e., s. 18.
} 


\section{Türkiye’de İstihdam Odaklı Asgari Gelir Desteğine Benzer Uygulama Örnekleri}

Türkiye'de henüz uygulamada olan bir asgari gelir desteği programı mevcut değildir. Bununla birlikte ASPB'nin bu konuda ciddi projeleri ve önerileri bulunmaktadır. Diğer taraftan geliri belli bir seviyenin altında bulunan yoksullara bir asgari gelir desteği verilmesi fikri akademik çevrelerde ve kamuoyunda tartışılan, özellikle siyasetçilerin sıklıkla dile getirdiği(vatandaşlık maaşı) bir konudur.

Türkiye'de uygulanan yardım programları içerisinde asgari gelir desteğine benzeyen ve kişiye geçimini sağlamak üzere düzenli olarak verilen, hak niteliğindeki yardımlar, 2022 Sayılı Kanun gereği çalışacak durumda olmayan yaşlılara ve özürlülere verilen yardımlardır. Kişiler SGK tarafından yürütülen bu özürlü ve yaşlı aylıklarından muhtaçlık durumları devam ettiği müddetçe yararlanabilmektedirler. Ayrıca çocuklara ve gençlere yönelik düzenli niteliği olan sosyal yardım programları da mevcuttur. Bu yardımlar çocukların ve gençlerin geçimini temin etmek üzere dizayn edilmemiştir. Yardımların amacı, çocukların sağlık kontrollerinin yapılması (şartlı sağlık yardımları) ve çocukların ve gençlerin eğitime devamlılıklarını (şartlı eğitim yardımları) sağlamaktır ve ancak bu şartlar yerine getirildiği takdirde yardıma hak kazanılmaktadır. Söz konusu yardımlar düzenli nitelikte olmaları sebebiyle asgari gelir desteğine benzemekle birlikte, kişinin geçimini sağlamaya yönelik olmadığı için daha farklı bir yapıdadır. Sağlık yardımı ayni nitelikte olup kişinin sağlık kontrolüne ihtiyaç duyması halinde sağlık masraflarının karşılanması suretiyle gerçekleştirilmektedir. Sağlık yardımı, amacı itibariyle ve nakit transferi olmaması sebebiyle asgari gelir desteğinden farklılaşmaktadır. Benzer şekilde ihtiyaç sahibi kimselere yönelik diğer sosyal yardım programları da arızi durumlarda düzensiz olarak yapıldıkları için asgari gelir desteğinden farklı bir yapıdadırlar. ${ }^{13}$

SYDV'lerin verdiği periyodik nakit yardımları da asgari gelir desteğine benzer uygulamalardır. Ancak bu yardımlar "hak temelli" olmadığından devamlılığı konusunda bir garanti bulunmamaktadır. SYDV yardımları istediği zaman kesebilmektedir.

Ayrıca devlet, ekonomik durgunluğun ve/veya işsizliğin yüksek olduğu dönemlerde geçici olarak istihdam yaratmak ve/veya özelleştirme vb. sebeplerle işsiz kalanları kamuda geçici işçi statüsünde (4 C Statüsü) istihdam etmek gibi faaliyetler içerisinde bulunmaktadır. Bu kişilere verilen maaşlar çoğunlukla asgari ücret seviyesinin biraz üstünde olup bir tür "istihdam programlı asgari gelir desteği” mahiyetindedir. Ancak istihdam edilenlerin muhtaçlik durumu tespiti yapılmadığından, istihdamın devamlılığı da söz konusu olmadığından istihdam sona erdiğinde ödenen maaş ta kesilmektedir. Diğer taraftan kişinin cebine belirli bir süre için de olsa düzenli, aylık, nakit bir para girdiğinden istihdam da gerçekleştiğinden az da olsa "istihdam programlı asgari gelir desteği” ile bir benzerlik söz konusudur. KOSGEB’in girişimciliği desteklemek üzere verdiği krediler, mesleki eğitim ve kurslar, yerel yönetimlerin verdiği sosyal yardımlar, mikro kredi uygulamaları da istihdam odaklılık ve asgari gelir desteği fikirleriyle ilintili projelerdir.

Türkiye’de 2022 Sayılı Kanun gereği verilen yaşlı ve özürlü yardımları ile Şartlı Nakit Transferleri asgari gelir desteğine en yakın uygulamalardır. Diğer uygulamalar ise gerek yoksullukla ve işsizlikle mücadele gerekse muhtaç kimselere bir nakit desteği olması boyutları ile "asgari gelir desteği uygulaması civarında" diye adlandırılabilecek uygulamalardır. Ayrıca "eşi vefat etmiş kadınlara yönelik düzenli nakit sosyal yardım programı" ile "evde bakım

${ }^{13}$ Kemal Madenoğlu, "Yoksullukla Mücadelede Asgari Gelir Desteği Türkiye’deki Uygulama”, Türk-İş Dergisi, 389, 2010, s. 38-39. 
yardım programı" da asgari gelir desteği benzeri programlardır. 29.12.2011 Tarih ve 2011/8 Sayılı Fon Kurulu Kararı ile başlatılmasına karar alınan eşi vefat etmiş kadınlara yönelik yardımlar BSYH Bilgi Sistemi bünyesinde gerçekleştirilmekte olup yardımın hedef kitlesi olarak 3294 Sayılı Kanun kapsamında olan kadınlar belirlenmiştir. ${ }^{14}$

\section{a) 2022 Sayılı Kanun Kapsamındaki Destekler}

ASPB’nin yürüttüğü faaliyetler içerisinde en önemlilerinden bir tanesi 2022 sayılı "65 Yaş1nı Doldurmuş Muhtaç, Güçsüz, Kimsesiz Türk Vatandaşına Aylık Bağlanması Hakkındaki Kanun" kapsamındaki aylıktır. 1 Ocak 1977 tarihinde yürürlüğe giren bu kanun "muhtaç olmak koşulu ile 65 yaşını doldurmuş yaşlılar ile 18 yaşından büyük özürlüler ve kanunen bakmakla yükümlü olduğu 18 yaşını tamamlamamış özürlü yakını bulunan Türk vatandaşlarına aylık bağlanmasını" sağlamıştır. ${ }^{15}$

Tablo.2: 2022 Sayılı Kanuna Göre Yapılan Ödemeler (Kişi Sayısı), (2006-2011)

\begin{tabular}{|c|c|c|c|c|c|c|}
\hline & 2006 & 2007 & 2008 & 2009 & 2010 & 2011 Aralık \\
\hline Yaşlılık & 927.077 & 903.283 & 867.035 & 859.516 & 848.826 & 797.426 \\
\hline Malullük & 82.891 & 92.904 & 114.518 & 142.288 & 168.559 & 187.711 \\
\hline Sakatlık & 233.910 & 239.110 & 255.990 & 275.028 & 290.558 & 293.141 \\
\hline $\begin{array}{l}18 \text { Yaş Altı } \\
\text { Sakat-Malul }\end{array}$ & - & 8.877 & 28.631 & 44.541 & 55.727 & 59.558 \\
\hline $\begin{array}{l}\text { Özürlü } \\
\text { Silikoziz } \\
\text { Hastaları }\end{array}$ & - & - & - & - & - & 153 \\
\hline TOPLAM & 1.243 .878 & 1.235 .297 & 1.266 .174 & 1.321 .373 & 1.363 .670 & 1.337 .989 \\
\hline
\end{tabular}

Kaynak: SGK, SGK İstatistik Yıllıkları 2010: Aylık ve Gelir Alanlara Ait İstatistikler: Çalışma ve Sosyal Güvenlik Bakanlığı, Çalışma Hayatı İstatistikleri 2011, Ankara, Ağustos 2012, s. 33.

Tablo. 2'de görüleceği üzere 2022 Sayılı Kanun kapsamındaki ödemeler içerisinde en büyük pay yaşlılara aittir.

Söz konusu yardımlar yoksul kişilere aylık, düzenli bir nakit desteği olması yönü ile asgari gelir desteği yardımına benzemekle birlikte yardımın bağlanmasına belli bir şart-özellik itibari ile karar verildiğinden bu yardımların farklı bir yardım türü olarak değerlendirilmesi daha doğru olacaktır. Diğer taraftan 2022 Sayılı Kanun’un muhatabı olan kesim çalışma yaşında ve/veya yeteneğinde olmadığından aktivasyon unsurları içermemektedir.

\section{b) Sosyal Riski Azaltma Projesi-Şartlı Nakit Transferi}

Dünya Bankası’nın Türkiye için hazırladığı Sosyal Riski Azaltma Projesi (SRAP) öncesinde yapılan yoksulluk araştırması Türkiye'de yoksulluğun ciddi boyutlara ulaştığını göstermiştir. Projenin temelinde yatan düşünce Türkiye'de Şubat 2001'de yaşanan ekonomik krizin yoksul kişiler üzerinde oluşturduğu riskle mücadeledir. Kriz nedeniyle işten çıkarmalar artmış, fiyatlar yükselmiş, negatif büyüme nedeniyle hanelere giren gelir azalmış ve yoksulluk riski artmıştır. Bu noktada yapılan diğer bir saptama Türkiye'de işsizlik ve yoksulluk riskleri-

\footnotetext{
${ }_{14}$ Aile ve Sosyal Politikalar Bakanlığı, Sosyal Yardımlar Genel Müdürlüğü, 2012 Sosyal Yardım İstatistikleri Bülteni, 2012, s. 49.

${ }^{15}$ Faruk Taşçı, Sosyal Politikalarda Can Simidi Sosyal Yardım, Ankara: Nobel Yayın Dağıtım, 2010, s. 90.
} 
ni azaltmak üzere bir sosyal güvenlik ağının bulunmayışıdır. Diğer taraftan çocuk ve anne ölüm oranlarının çok yüksek olması, kadınların okur-yazarlık oranlarının çok düşük olması, yoksul ailelerin ekonomik sıkıntılar nedeniyle çocuklarını okula gönderemeyişi bazı ailelerin geçimini çocuk emeği ile sağlaması gibi pek çok beşeri sermaye ile ilgili etmen de söz konusudur. ${ }^{16}$

Şartlı Eğitim ve Sağlık Yardımları Programı, Türkiye'de, yoksulluk nedeniyle eğitim ve sağlık alanında sunulan hizmetlerden faydalanamayan muhtaç durumdaki ailelerin nakit transferleri yoluyla bu hizmetlere ulaşmasını hedeflemektedir. Daha açık bir ifade ile Şartlı Eğitim ve Şartlı Sağlık Yardımları, 3294 sayılı Sosyal Yardımlaşma ve Dayanışmayı Teşvik Kanunu kapsamında; yoksulluk nedeniyle çocuklarını okula gönderemeyen ya da okuldan almak zorunda kalan, okul öncesi çocuklarının sağlık kontrollerini düzenli olarak yaptıramayan ve doğumlarını bir sağlık kuruluşunda gerçekleştiremeyen yoksul durumdaki aileleri desteklemeyi hedefleyen nakdi bir sosyal yardım programıdır.

Türkiye’de zorunlu eğitimin sekiz yıla çıkarılması başta olmak üzere, son yıllarda çocuk işçiliğiyle mücadelede etkili adımlar atılmasına rağmen, çocuk işçiliğinin ve daha genel olarak, çocuk yoksulluğu sorununun hala önemini korumakta olduğu görülmektedir. Çocuk yoksulluğu sorununun sosyal politika gündeminde olduğunun somut bir göstergesi, Dokuzuncu Beş Yıllık Kalkınma Planının bu konuda net hedefler içermesidir. Bu tedbirler şu şekildedir:

- Özellikle kırsal kesimdeki kız çocuklarının, özürlülerin ve düşük gelirli ailelerin çocuklarının eğitim ihtiyaçlarının karşılanması desteklenerek bu kesimlerin eğitime erişimleri kolaylaştırılacaktır. Ayrıca, çocuk işçiliğini önleyecek tedbirler alınacak ve etkili bir şekilde uygulanacaktır.

- Çocuğun bakımı ve yetiştirilmesi için ideal ortam olan aileye yönelik eğitici programlar yaygınlaştırılacaktır. ${ }^{17}$

Ancak çocuk yoksulluğu konusunda atılmış asıl önemli adımlardan biri, kuşkusuz Şartlı Nakit Desteği programının 2002 yılında başlatılmış olmasıdır. Türkiye’de ŞNT programları 2001 yılındaki ekonomik kriz sonrası Dünya Bankasından sağlanan krediyle uygulamaya konulan Sosyal Riski Azaltma Projesi (SRAP) ile başlamıştır. İlk olarak Kahramanmaraş-Göksun, Gaziantep-Yavuzeli, Sinop-Durağan, Ankara-Keçiören, Çankırı-Merkez ve Zonguldak-Ereğli İlçelerinin pilot bölgeler seçilmesiyle başlatılan program, 2 yıl içerisinde aşama aşama tüm Türkiye'ye yaygınlaştırılmıştır. ${ }^{18}$

ŞNT programları, tüm dünyada, çocukların sağlıklı bir vücut bütünlüğüne sahip olmasın$\mathrm{da}$, eğitimlerinin çalışma zorunluluğu ve yoksulluk nedeniyle kesintiye uğramamasında ve çocuk işçiliğinin önlenmesinde etkisini kanıtlamış programlardır. Çocuk yardımları aslında tarihsel olarak refah devleti uygulamalarının başlangıcından bu yana sürekli önemli bir yer tutmuş ve yeni yaklaşımlarla sürekli bir gelişim ve dönüşüm içinde olmuştur. ŞNT programları da bu kapsamda değerlendirilmelidir.

Yukarıda belirtilen temel hedefler bağlamında, Türkiye’de ŞNT çocukların temel sağlık ve

\footnotetext{
${ }^{16}$ Filiz Çulha Zabcı, "Sosyal Riski Azaltma Projesi: Yoksulluğu Azaltmak mı, Zengini Yoksuldan Korumak mı?”, Ankara Üniversitesi SBF Dergisi, 58/1, 2003, s. 228-229.

${ }^{17}$ İlhan Karakoyun, Fuat Erdal, "Şartlı Nakit Transferleri ve Çocuk Yoksulluğu ile Mücadele: Sosyal Riski Azaltma Projesi (SRAP) Şartlı Nakit Transferi (ŞNT) Bileşeni: Aydın İli Uygulaması”, Finans, Politik ve Ekonomik Yorumlar, 46/529, 2009, s. 22.

${ }^{18}$ a.g.e., s. 22.
} 
eğitim hizmetlerine tam olarak erişmelerini teşvik etmek amacıyla nüfusun en yoksul \% $6^{\prime}$ lık kesimini hedef alan bir sosyal güvenlik ağı olarak tasarlanmıştır. Bu kapsamda, dünyadaki ülke örneklerinde olduğu gibi, eğitim ve sağlık yardımları şeklinde iki tür ŞNT verilmektedir. Daha açık bir ifadeyle, ŞNT, yoksulluk nedeniyle çocuklarını (özellikle kız çocuklarını) okula gönderemeyen veya okuldan almak zorunda kalan ailelerin çocuklarını düzenli okula göndermeleri ve 0-6 yaş grubu çocuğa sahip olan ailelerin de çocuklarını düzenli sağlık kontrolüne göndermeleri şartına bağlı olarak yapılan düzenli nakit yardımlar şeklinde gerçekleşmektedir. Ayrıca yoksul anne adaylarının, gebelik süresince düzenli olarak doktor kontrolüne gitmeleri ve sağlık kurumunda doğum yapmaları şartlarına bağlı olarak da ayrı ayrı yardımlar verilmektedir. Eğitim yardımlarının miktarı çocukların yaşı, cinsiyeti, devam ettiği eğitim kurumunun seviyesine bağlı olarak farklılaştırılmış, kız çocukları ve daha üst eğitim kurumları için daha yüksek miktarlarda nakit ödemeler yapılmıştır. 2009 Eylül Ayı itibariyle eğitim yardımlarından faydalanan çocuk sayısı 2.066.809, sağlık yardımlarından faydalanan 0-6 yaş grubu çocuk sayısı 787.000, anne adaylarının sayısı ise 48.597 olarak gerçekleşmiştir. ${ }^{19}$ Belirtilmesi gereken bir başka önemli nokta da yine dünyadaki örneklerle benzer şekilde, bu nakit transferlerin, doğrudan doğruya annelere yapılmakta oluşudur. Bu sayede, desteğin aile ve özellikle de çocuklar yararına harcanma ihtimalinin kuvvetleneceği öngörülmektedir.

Eğitim yardımları da benzer biçimde, çocukların eğitimden kopup, erken yaşta çalışma hayatına atılmasını önlemek amacıyla, dar gelirli ve yoksul hanelere çocuklarını düzenli olarak okula göndermeleri şartıyla aylık olarak verilmektedir. Eğitim yardımları da tıpkı sağlık yardımlarında olduğu gibi doğrudan annelere yapılmaktadır.

ŞNT programları Türkiye'de Dünya Bankası Sosyal Riski Azaltma Projesi kapsamında uluslararası kredi desteğiyle başlamış olmakla birlikte, projenin sona erdiği 2006 yılından sonra ulusal kaynaklarla devam ettirilmiş ve bir kesintiye uğramamıştır. Bunda kuşkusuz programdan elde edilen başarılı sonuçlar etkili olmuştur. ŞNT’nin ilk ayağı sayılabilecek proje süresi kapsamında toplam 357,7 milyon \$ tutarında harcama yapılmış; sonrasında ŞNT harcamaları Sosyal Yardımlaşma ve Dayanışmayı Teşvik Fonu (SYDTF) kaynaklarından karşılanmaya başlamıştır. Bu kapsamda yerel vakıflar, temel yürütücü birimler rolünü üstlenmiştir. ŞNT programı için 2003-2010 dönemi eğitim, sağlık ve gebelik yardımları için toplam aktarılan kaynak tutarı 1,99 Milyar TL'dir. Aktarılan kaynak miktarı çok yüksek bir meblağ olduğundan SYDGM programları içerisinde ayrı bir önem taşımaktadır.

Öte yandan, Türkiye’de ŞNT yardımlarının tamamen nesnel kurallara göre, sıkı bir merkezi denetim altında dağıtılması öngörülmüştür. Buna rağmen, uygulamada yerel uygulayıcıların yaklaşımlarını yansıtan farklılıklara rastlamak da mümkündür. Yani hem katı bir merkezilik hem de yerel koşullara uygun bir esneklik bir arada yürütülmeye çalışılmaktadır. Örneğin, doğum oranlarında hızlı bir artış yaşanmasının arzu edilmediği bazı bölgelerde, hamilelik yardımı uygulanmamıştır. ${ }^{20}$

\section{c) Evde Bakım Hizmeti}

Evde bakım hizmetleri 5378 Sayılı Özürlüler Kanunu çerçevesinde uygulanmakta olup amacı bakıma muhtaç olan özürlü kişiye kendi aile çevresinden birisinin ev ortamında bakması-

\footnotetext{
${ }^{19}$ Yusuf Alper, Rabihan Yüksel Arabacı, "Yoksullukla Mücadele, Vatandaşlık Geliri ve Aile Ödenekleri Sigortası”, Türk-İs Dergisi, 389, 2010, s. 47.

${ }^{20}$ Buğra, Keyder, Erdem, a.g.e., s. 18.
} 
nı sağlamaktır. Aynı zamanda bu şekilde özürlü kişiye sistemli ve nitelikli bakım hizmetlerinin verilmesi amacı güdülmektedir. Özürlünün bakımını üstlenen aile ferdi her ay bir aylık net asgari ücret tutarında bir maaş almaktadır. ${ }^{21} 2006$ yılında 8 kişi evde bakım hizmeti aylığ 1 alırken 2012 yılı Ağustos Ayı́nda söz konusu maaşı alan kişi sayısı 387.097 kişi olarak gerçekleşmiştir. ${ }^{22}$ ASPB yetkilileri ile yapılan derinlemesine mülakatta Bakanlık yetkilileri evde bakım hizmeti maaşı alan kişiler hakkında sosyal yardım-istihdam bağlantısı kurulması ile ilgili olarak yapılan çalışmalardan söz etmişlerdir. Buna göre, Bakanlık bünyesinde evde bakım aylığı alan kişilerin sigorta primlerinin devlet tarafından ödenmesi ve Genel Sağlık Sigortası kapsamına alınmaları ile ilgili çalışmalar yapılmaktadır. Genellikle uzun süreçli olan bu bakım işleri esnasında kişinin başka bir işte çalışması mümkün olmadığından özürlü kişi vefat ettiğinde ya da bir şekilde yardım gereksinimi ortadan kalktığında evde bakım hizmetini gerçekleştiren kişi sigortasız ve aynı zamanda işsiz olarak toplumdaki yaşamına geri dönmektedir. Bu noktada Bakanlığın önerisi büyük önem arz etmektedir. ${ }^{23}$

\section{d) Yerel Yönetimler}

Yerel yönetimler, devlet sınırları içinde kalan ortak ve yerel nitelikteki gereksinmeleri karş1lamak üzere belli hukuk düzeninde yer alan irili ufaklı topluluklardan (kent, kasaba, köy v.b.) oluşmaktadır. Günümüzde birçok ülkede olduğu gibi ülkemizde de yerel yönetimler yoksullukla mücadelede önemli işlevleri yerine getirmektedirler. Yerel yönetimlerin, yoksullukla mücadelesinin başlıca nedenleri; yoksulların demokratik katılım bilincinin geliştirilmesi, bazı kamu hizmetlerinin daha kolay ve pratik sunulabilmesi, merkezi yönetimden kaynaklanan eksikliklerin giderilmesi ve yoksullukla ilgili bilgi ve bilinç düzeyinin artırılması şeklinde sınıflandırılabilir. ${ }^{24}$

Türkiye'de belediyeler de sosyal yardım veren kuruluşlar arasında yer almaktadır. Özellikle 2005 yılında belediyeler yasasının değişmesiyle birlikte belediyelere yeni görev ve sorumlulukların verilmesi bu süreci hızlandırmıştır. Belediyelerin verdikleri sosyal yardımlara ilişkin derlenmiş veri olmadığ 1 için burada ayrıntılı olarak yer verilmemiştir. ${ }^{25}$ Bununla birlikte özellikle ekonomik krizlerin olduğu, yoksulluk ve işsizliğin yüksek seviyelerde seyrettiği durumlarda belediyelerin asgari bir ücret vermek suretiyle geçici olarak işçi istihdam ettiği, uygulamadan bilinmektedir. Türkiye'de birçok il ve ilçe belediye'sinde bu tip uygulamalar gerçekleşmektedir. Söz konusu uygulamalar bir anlamda kamu ve sosyal hizmetleri yapma vasıtası ile işsiz kişileri asgari bir gelirle destekleme mahiyeti taşımaktadır. Ayrıca birçok AB ülkesinde aktivasyon prensibi gereği, asgari gelir desteği yardımı alanlar yerel yönetimlerin yönlendireceği birtakım toplumsal hizmetlerde ve projelerde çalışmaya teşvik edilmektedir. Diğer taraftan Belediyeler Kanunu'nun belediyenin giderlerini düzenleyen 60. maddesinde, dar gelirli, yoksul, muhtaç ve kimsesizler ile özürlülere yapılacak sosyal hizmet ve yardımlar da belediye giderleri arasında sayılarak, belediyelerin bu tür hizmetler için kaynak ayırmala-

\footnotetext{
${ }^{21}$ Aile ve Sosyal Politikalar Bakanlığı, a.g.r., s. 101.

22 Özürlü ve Yaşlı Hizmetleri Genel Müdürlüğü, Yaşlanma Ulusal Eylem Planı Uygulama Programı Taslağı, Ankara, 2012, s. 17.

${ }^{23}$ ASPB Sosyal Yardımlar Genel Müdürlüğünde Samet Güneş ve Fatih Ortakaya ile Yapılan görüşme, Ankara, 26 Haziran 2014.

${ }^{24}$ S. Mustafa Önen, "Yerel Yönetimlerin Yoksullukla Mücadelesi: Malatya Belediyesi Örneği”, Sayıştay Dergisi, 79, 2010, s. 68.

${ }^{25}$ Ülker Şener, "Yoksullukla Mücadelede Sosyal Güvenlik, Sosyal Yardım Mekanizmaları ve İş Gücü Politikaları”, TEPAV Politika Notu, Şubat 2010, s. 17.
} 
rı gerektiği hususu belirtilmiştir. ${ }^{26}$

\section{e) Mikro Kredi}

Türkiye'de 2001 krizinden sonra benimsenen bir başka yoksullukla mücadele aracı da bireyleri girişimciliğe teşvik etmek üzere uygulanmaya başlanan mikro-kredi projeleridir. Mikro-finans projeleri ile gerek kır gerek kentte bireyleri kendi işlerini kurmaya teşvik etmek ve girişimcilik potansiyellerini yaşama geçirmelerini sağlamak amaçlanmaktadır. Böylece bireylerin olası kriz durumlarına hazırlıklı olmaları ve bu tür durumlarda çözümleri devletten beklemek yerine kendi kapasite ve becerilerini devreye sokmaları istenmektedir. Özellikle yoksul kadınların girişimcilik potansiyellerini desteklemeyi amaçlayan mikro finans projeleri çeşitli vakıflar tarafından uygulanmaktadır. Bu çerçevede Kadın Emeğini Destekleme Vakfı (KEDV) 2002'de kurduğu mikro ekonomik destek işletmesi ile özellikle yoksul kadınlara kendi işlerini kurmaları konusunda finansal ve teknik destek sağlamaktadır. ${ }^{27}$

Mikro kredi bir sosyal yardım türü olan asgari gelir desteği ile doğrudan bağlantılı bir yoksullukla mücadele metodu değildir. Bununla birlikte yoksul kişilere nakdi bir destek verilmek suretiyle kendi projelerini oluşturma ve yoksulluk kısır döngüsünü kırma imkan ve olasılığı sağladığından fonksiyonları itibariyle asgari gelir desteği ile benzerlikler mevcuttur.

\section{AB Ülkelerindeki Uygulamalar Ișı̆̆ında Türkiye’de İstihdam Odaklı Asgari Gelir Deste- ğinin Oluşturulması için Öneriler}

AB ülkeleri incelendiğinde bazı ülkelerde garantili asgari gelir projesinin "tek mevcut güvenlik ağı” olduğu diğer bazı ülkelerde ise asgari gelir desteğinin çeşitli ödeneklerin ve ilgili hakların da dâhil olduğu daha geniş bir sosyal güvenlik ağının bir parçası olduğu görülmektedir. Türkiye için ise potansiyel olarak düşünülecek bir asgari gelir desteği programını, sosyal yardımlar bünyesinde yeni bir “yardım türü” olarak düşünmek uygun olacaktır, şu ana kadar ASPB bünyesinde yürütülen çalışmalar da zaten bu doğrultudadır.

Gelir desteğine ihtiyacı olanları temel olarak üç şekilde düşünmek mümkündür. Birinci grupta çalışan "yoksullar” yer almakta olup bu kişiler çalıştığı halde gelir desteğine ihtiyacı olanlardır. Gerek AB ülkelerindeki uygulamalarda gerekse dünyanın başka bölgelerindeki uygulamalarda çalışan yoksulların da asgari gelir desteğinden faydalanabildiği durumlar söz konusudur. Başlangıçta olmasa bile uygulamanın ileriki safhalarında Türkiye için de asgari gelir desteğinin çalışan yoksullara verilebilmesi konusu tartışılmalıdır.

İkinci grup çalışma isteği ve yeteneği olduğu halde iş bulamadığı için gelir desteğine ihtiyacı olanlardan oluşmaktadır; bu kişiler işsizdir. Türkiye'de işsizlik yardımı almaya hak kazananlar belli bir süre bu yardımdan faydalanmaktadırlar, ancak kişi süre bittiğinde ve yardım kesildiğinde eğer hala istihdam edilmemişse maddi olarak sıkıntıya girmektedir. Bu durumda işsizlik yardımı ödemeleri bittikten sonra işsizlerin asgari gelir desteği almalarını sağlamak uygun olacaktır. Ayrıca işsizlik yardımını hak etmeyenler de direkt olarak asgari gelir desteğinin muhatabı olmalıdır. AB'de bu konuda farklı uygulamalar söz konusu olup örneğin işsiz kalan kişiler çeşitli ödenekler içerisinde miktarı daha fazla olanı seçebilmektedir. Diğer

\footnotetext{
${ }^{26}$ Nilüfer Negiz, "Sosyal Yardım ve Sosyal Hizmet Faaliyetleri Açısından Isparta Belediyesi: Farkındalık, Yararlanma ve Değerlendirme Açısından Bir Araştırma”, Süleyman Demirel Üniversitesi İktisadi ve İdari Bilimler Fakültesi Dergisi, 16/2, 2011, s. 329.

${ }^{27}$ Didem Gürses, “Türkiye'de Yoksulluk ve Yoksullukla Mücadele Politikaları”, Balıkesir Üniversitesi Sosyal Bilimler Dergisi, 17/1, 2007, s. 59-74.
} 
taraftan bazı ülkelerde asgari gelir desteği bir tür işsizlik sigortası gibi kişi işsiz kaldığı müddetçe ödenmeye devam edilmektedir.

Üçüncü grupta ise çalışma yeteneği olmayan veya çeşitli nedenlerle çalışma imkanı bulamayan ve gelir desteğine ihtiyaç duyanlar (hasta, yaşlı, özürlü, kadın, çocuk, eski hükümlü, marjinal gruplara mensup kişiler) yer almakta olup bu kişiler dezavantajlı grubu oluşturmaktadır. AB uygulamalarında dezavantajlı gruplara yönelik çeşitli kategorik uygulamalar-ödenekler söz konusudur, Türkiye’de ise bu tür uygulamalar daha sinırlıdır. Dezavantajlı gruplara mensup kişiler kategorik yardımlardan faydalansa da faydalanmasa da asgari seviyede geçimlerini sağlayabilmek açısından desteklenmelidirler.

Diğer taraftan, $\mathrm{AB}$ ülkelerinde özellikle son on yılda asgari gelir desteği sistemleri ile ilgili olarak en dikkat çekici nokta aktivasyon konularına ağırlık verilmesidir. Yoksullara asgari bir gelir desteği vermek nihai/ulaşılmaya çalışılan bir hedef olmayıp asıl hedef yoksulların bu tür bir sosyal yardımla geçimlerini minimum seviyede karşılamalarını sağlamak diğer taraftan ise aktif istihdam politikalarıla desteklemek suretiyle emek piyasasına yeniden girmelerini ve kendi geçimlerini kendilerinin sağlamalarını temin etmektir. Diğer taraftan aktivasyonun gerçekleştirilebilmesi ile ilgili olarak ülkenin iktisadi yapısı (büyüme, GSMH vb. makro ekonomik veriler), istihdam ve işsizlik oranları vs. kısıt oluşturabilmektedir, bu konular Türkiye için de kısıt oluşturabilecek konulardır.

Asgari gelir desteği alan kişiler bir taraftan çalışmaya yönlendirilirken diğer taraftan da gerek mesleki eğitim vermek suretiyle bu kişilerin vasıflarını arttırmak gerekse daha nitelikli işlerde istihdam edilmelerini ve dolayısıyla daha yüksek ücretler almalarını sağlamak büyük önem arz etmektedir. AB ülkelerindeki aktivasyon uygulamalarına yönelik eleştirilerden bir tanesi sosyal yardım alan kişilerin vasıfsız ve düşük ücretli işlerde istihdam edilmesidir. Bu yönüyle “düzgün iş”(decent work) kavramına vurgu yapılmaktadır. Türkiye için asgari gelir desteği uygulaması yeni başlayacak bir uygulama olduğundan daha başlangıçta bu tip olumsuzluklar dikkate alınmalı ve sistem aktive edilecek kişileri (gerekiyorsa mesleki eğitim de verilmek suretiyle) mümkün olduğunca nitelikli ve yüksek ücretli işlere yönlendirmelidir. Açıkça görülmektedir ki ülkemiz için mesleki eğitim ve mesleğe yöneltme çalışmaları da en az iş bulma kadar büyük önem arz etmektedir. Bunun sebebi hem mevcut muhtaç kişilerin eğitimsiz kişilerden oluşması hem de okullarda verilen eğitimin iş yaşamının gereksinim ve ihtiyaçlarını karşılama noktasında yetersiz olmasıdır.

Asgari gelir desteği sisteminin oluşturulmasında ülkede hâlihazırda işlemekte olan sosyal güvenlik sisteminin yoksullukla mücadele ve adaletli gelir dağılımını sağlamak hakkında ne derecede başarılı olduğu ve ülkenin vergilendirme sistemi önemli bir zemin teşkil etmektedir. Asgari gelir desteği sistemi bu zeminle uyumlu bir biçimde inşa edilmelidir. Örneğin İsveç diğer İskandinav ülkeleri gibi cömert ve kapsamlı bir sosyal güvenlik sistemine sahip olduğundan, ayrıca evrensel ve katkı ödenekli yardımlar da sosyal güvenlik sistemine dahil olduğundan sosyal yardımların etkisi diğer sosyal güvenlik mekanizmalarına göre daha azdır. Türkiye'de de mevcut sosyal güvenlik ve sosyal koruma sistemine uygun bir asgari gelir desteği programının inşasına gereksinim vardır. Gerek sosyal güvenlik ödenekleri gerekse sosyal koruma ile ilgili yardımlar özellikle miktar ve kapsam açısından yetersiz olduklarından bir son çare uygulaması olarak asgari gelir desteğinin daha kapsayıcı olması ve yeterli miktarda verilmesi fonksiyonel olacaktır.

Diğer bir konu ise asgari gelir desteği yardımlarının yönetilmesinde yerel yönetimlerin mi yoksa merkezi hükümetin mi daha fazla yetki sahibi olacağına ilişkindir. AB ülkelerinden 
örneğin Avusturya'da toplumsal yardım işlerinde çalışma karşılığında verilen ve "yurttaş geliri” olarak isimlendirilen asgari gelir desteğine hak kazanacak kişilerin tespiti ve uygulama yerel yönetimlerin inisiyatifine bırakılmıştır. Türkiyede de yerelde mevcut durumu ve şartları daha yakından gözlemleyebilme imkanı olan sosyal hizmet görevlilerinin inisiyatif ve sorumluluğunu arttırmak mümkündür. ASPB'nin görüşleri de bu doğrultuda olup sosyal hizmet görevlilerinin inisiyatif kullanmalarına izin verme şeklinde proje ve görüşlerini kamuoyu ile paylaşmaktadırlar. Diğer taraftan inisiyatif kullanacak bu sosyal hizmet görevlilerinin adil davranmalarını sağlamak çok önemlidir. Ayrıca Avusturyada 1994 yılından itibaren dokuz yerel bölgenin özel sorumluluğunda olan asgari gelir desteği daha genel, kapsayıcı ve dağıtımcı olmayan bir yapıdadır, diğer ekonomik destekler ise daha çok dağıtımcı yardımlar rolü üstlenmektedir. Aynı zamanda yüksek bir harcama seviyesine sahip olan Avusturya'da sosyal transferlerden sonra yoksulluk \%72,1 oranında azaltılmaktadır. Söz konusu sistem ve yapı Türkiye için de uygulanabilir olup özellikle yoksulluğu azaltmaktaki başarısı dikkat çekicidir.

AB ülkelerinde asgari gelir istihdam bağlantısına ilişkin olarak teşvik edici birçok uygulama söz konusudur. Örneğin; İngiltere'de haftada 16 saat veya daha fazla çalışanlar yardıma hak kazanmaktadır. Yardım alanın eşi ise 24 saat veya daha fazla çalışması durumunda yardıma hak kazanmaktadır. Aktivasyon açısından bu tip teşvikler Türkiye için de uygun olacaktır. Diğer taraftan İngiltere örneğindeki tipte uygulamalar ile esnek çalışma biçimleri ile de uyumlu bir politika izlenmiş olacaktır.

Asgari gelir desteği belirlenmesinde "yoksulluk" veya "gelir eşiği” veya "eşik" veya "azami kaynak eşiğì" ne olacağı konusu diğer önemli bir konudur. AB ülkelerinin bu konudaki uygulamalarına bakıldığında kendi sosyo-ekonomik, siyasal tercihleri doğrultusunda bir seçim yaptıkları görülmektedir. Örneğin "Socialbidrag” sistemini benimsemiş olan İsveç’te yardımı hak etmek için kişinin sahip olduğu kaynakların ülke için belirlenmiş bulunan "azami kaynak eşiği”nin altında olması gerekmektedir. Türkiye kamuoyunda yoksulluk tespiti ile ilgili farklı eğilimler/uygulamalar mevcuttur; TÜİK medyan gelirin \%40’ının altını yoksul olarak kabul etmektedir. ASPB SYGM ise yoksulluk tespitini yaparken birçok veriyi göz önünde bulundurmaktadır. SYGM gerek yapmış olduğu hane ziyaretlerindeki puanlama sisteminden elde ettikleri veriler ve katsayılar gerekse bütünleşik yardım sistemi ve SOYBİS veri tabanıyla sahip oldukları bilgiler ışığında kişinin yoksul olup olmadığına ve yardım almayı hak edip etmediğine karar vermektedir. Türkiyede şu ana kadar asgari gelir desteği programı ile ilgili yürütülen çalışmalarda siyasi irade, asgari gelir desteği muhataplarının kişi başı günlük geliri 4,3 USD’nin altında kalanlar olabileceğini belirtmiştir. ${ }^{28}$ Özetle belirtmek gerekirse, Türkiye için asgari gelir desteği muhataplarının belirlenmesinde yoksulluk eşiğinin ne olacağına dair bir mutabakata ihtiyaç vardır.

AB ülkelerindeki uygulamalarda muhtaçlık tespitinin gelir testi ile yapıldığı görülmektedir; Türkiye için de benzeri bir uygulama söz konusu olabilir. Diğer taraftan kayıt dışı istihdamın bugünkü boyutlarının çok yüksek olᄀduğu Türkiye’de, gelir tespiti çalışmaları çok kolay olmayacaktır. Ayrıca gelir testli sosyal yardımlar için bir bilgisayar sistemini yürütmek te oldukça zordur, bireylerin gelirleri, ailedeki fert sayısı, yaş gibi unsurlar sürekli değişim gösteren parametrelerdir ve bu rakamları milyonlar için takip etmek oldukça güçtür. Nitekim $\mathrm{AB}$ ülkelerinde de sosyal yardım sistemini bilişim sistemi yardımı ile yürütme çabaları ve

${ }^{28}$ ASPB Sosyal Yardımlar Genel Müdürlügü’nden Samet Güneş ve Fatih Ortakaya ile Yapılan Görüşme, 26 Haziran 2014. 
bu alandaki sorunlar gerek ülke parlamentolarında gerekse kamuoyunda sürekli tartışllan konulardır. Sistemi yürütmek hem zordur hem de çok yüksek maliyetlidir. Bununla birlikte ASPB'nin bilişim sistemleri alanında oldukça ileri seviyede olduğu bilişim alanında almış olduğu ödüllerden bilinmektedir. Ayrıca Bakanlık yetkilileri uygulanmakta olan Soybis ve Bütünleşik Yardım Sistemi Programlarının AB ülkelerine yapmış oldukları ziyaretlerde de takdirle karşılandığını ifade etmişlerdir. ASPB ziyareti esnasında SYGM yetkililerinin bilişim sistemlerini etkin ve fonksiyonel kullanmak suretiyle gerek yardım alacak kişileri belirlemede gerekse yardımın verilmesinde başarılı bir işlem gerçekleştirmeye çalıştıkları gözlemlenmiştir. Bu çerçevede ASPB'nın bilişim alanında avantajlara sahip olduğunu ifade etmek yanlış olmayacaktır. Diğer bir konu AB ülkelerinde gerek istihdam-işsizlik sorunu gerekse finansman sorunu gibi nedenlerle asgari gelir desteği yardımlarının aktif emek piyasası tedbirleriyle desteklenmesinin gerekliliğidir. Ayrıca AB ülkelerinde doğuştan yaşam ümidinin yüksek olması, teknolojinin ve iyileşen yaşam koşullarının da etkisiyle yaşam sürelerinin artması, emeklilik yaşı yükseltilse dahi çok uzun yıllar emeklilik ödemelerinin devam etmesine yol açmaktadır. Diğer taraftan, doğumların azalması ve genç nüfus oranının da düşük olması nedeniyle söz konusu emeklilik ödemelerini destekleyecek bir ödeme altyapısını gerçekleştirmek mümkün olmamakta ve hükümetler emeklilik ödemelerinin finansmanında büyük zorluklarla karşılaşmaktadırlar. Söz konusu ödemelerin desteklenebilmesi için çalışma çağındaki nüfusa ve bu nüfusun istihdam ile aktive edilmesine ihtiyaç vardır. Türkiye ise demografik geçiş sürecinde henüz ikinci aşamada olduğundan nispeten şanslı konumdadır, AB ülkelerine nazaran daha genç bir nüfusa sahiptir. Bununla birlikte gerek emeklilik ödemelerinin finansmanı gerekse asgari gelir desteğinin finansmanı Türkiye için de zor konulardır ve aktivasyon Türkiye için de gereklidir.

Türkiye’de asgari gelir desteği sisteminin kurulması ve aktivasyona ağırlık verilmesinde $A B$ ülkelerindeki deneyimlerden istifade edilmesi çok önemlidir. 2008 yılı ve öncesinde yaşanan küresel bölgesel ekonomik krizler ve küreselleşme Türkiye'de de finansman konusunda ciddi sıkıntılar yaşanmasına yol açmıştır. Dolayısıyla asgari gelir desteğinin daha inşası sırasında, getireceği mali yük hesap edilmek suretiyle aktivasyonu ön planda tutan bir model önerilmesi uygun olacaktır. Bununla birlikte aktivasyon konusu yardım alan kişiler üzerinde bir dayatma şeklinde uygulanmamalı ve kişiler bir taraftan iş bulamama sıkıntısı ile boğuşurken diğer taraftan verilen asgari gelir desteğinin azaltılması ya da tamamen kesilmesi tehdidi ile karşı karşıya kalmamalıdır.

Türkiye’de asgari gelir desteği ile ilgili tartışmalar kamuoyunda arttıkça en fazla gündeme gelecek konulardan bir tanesi finansman konusudur. ASPB SYGM'de yetkililerle yapmış olduğumuz derinlemesine mülakatlarda Bakanlığın bu konuda yapmış olduğu projeksiyonlar aşağıda özetlenmiştir. Buna göre;

ASPB “Temel Aile Yardımı” adı altında yoksullara yönelik bir asgari yardım verilmesini planlamaktadır. Bu yardımın günlük geliri 4,3 USD’nin altında olanlara verilmesi öngörülmektedir. TÜİK verilerine göre Türkiye'de nüfusun \%2,27'si günlük 4,3 USD’nin altında bir gelirle yaşamaktadır. ASPB yaptığı projeksiyonlarda Temel Aile Yardımlarının aşağıda belirtilen 3 tip aileye verilmesine yönelik projeksiyonlarda bulunmuştur:

1.Tip; TÜİK'in tespitine göre geliri 4,3 USD'nin altında olan 250.000 hane olup, bu hanelere verilmesi planlanan temel aile yardımının yıllık tutarı 1,2 Milyar TLye tekabül etmektedir.

2.Tip; Toplumda had safhada yoksulluk yaşayan ve yaşamlarını sürdürmeleri için 
yardım verilmesi zaruri olan en kötü durumdaki 68.000 hanedir (117.00 kişi). Bu kişilere verilmesi planlanan temel aile yardımının yıllık tutarı 326 Milyon TLye tekabül etmektedir.

3.Tip; Asgari gelir desteği yardımının en geniş anlamda verildiği durumdur. Bu durumda 1,5 Milyon hane söz konusudur, Bakanlık bu 1,5 milyon hane içerisinde 870.000 haneyi hedeflemiş ve bu durumda 4,1 Milyar TL kaynak ayırılması gerektiği belirtilmiştir.

Bu konuda öncelikli olarak asgari gelir desteğinin ASPB’nin projeksiyonlarında belirttiği had safhada yoksulluk yaşayan 68.00 haneye verilmesi ve daha sonra ise aşamalı olarak daha az yoksullara doğru genişletilmesi önerilebilir. Genel bütçe ve vergilerin yanı sıra işsizlik sigortasından veya kamuda yapılması mümkün olan tasarruflarla da söz konusu miktarı finanse etmek mümkün olabilecektir.

Asgari gelir desteğinin verilmesinde aranan "faaliyet şartı", ücret karşıllı̆̆1 çalışma, iş arama, eğitim ve beceri geliştirme programına katılma veya "sosyal hizmet" niteliğinde bir işi yapma gibi farklı içeriklere sahip olabilmektedir. Yaşlılar ve hastalarla ilgilenmek, onlara ev işlerinde destek olmak, ilaçlarını almak, alışverişlerini yapmak, onlara kitap veya gazete okumak gibi işler sosyal hizmet niteliğindeki işlere örnek gösterilebilir, bunlar genellikle kişinin yaşadığı çevreyi iyileştirmeye yönelik yaptığı faaliyetlerdir. Çocuklarına bakmakta güçlük çeken ebeveynlere yardımcı olmak ta sosyal hizmet niteliğindeki işlere örnek gösterilebilir. Çevre temizliği, çiçek ve ağaç dikimi, evlerin boyanması, tamiri, bahçıvanlık işleri de yardım karşılığı yapılan faaliyetlerdendir. Bu faaliyetlerin bir kısmı kültürel ve geleneksel yapı nedeniyle ülkemizde uygulanamayabilir; evde yatılı kalıp çocuk bakmak, yaşlı bakmak gibi. Bununla birlikte kendi kültürel yapımıza uygun topluma yararlı faaliyetler bulmak mümkündür, örneğin öğrenci yurdu, kreş, yaşlı bakım evi gibi çeşitli kamu kuruluşlarında çalışmak, yerel yönetimlerin göstereceği işlerde çalışmak gibi faaliyetlerin kültürel açıdan bir sorun teşkil etmeyeceği düşünülmektedir. Diğer taraftan siyasal yapı, sosyo-ekonomik yapı, kültürel öğeler, hukuk ve insan hakları gibi birçok değerin, gerek siyasal karar alıcının gerekse kamuoyunun asgari gelir desteğine bakışı üzerinde etkili olduğu görülmektedir. Farklı ülkelerde farklı tipte asgari gelir desteği türlerinin ortaya çıkmış olması tüm bu değerler ve bakış açısı ile ilintilidir. Türkiye de AB ülkeleri ve dünya üzerindeki diğer ülkelerdeki uygulamaları dikkate almalı bununla birlikte kendi “özgün” modelini üretmelidir.

Asgari gelir desteği uygulamasının başta kadınlar, çocuklar, yaşlılar olmak üzere tüm dezavantajlı gruplar üzerinde olumlu bir etkisi olacağı açıktır. Bununla birlikte bu gruplarda sadece çalışma çağında olup çalışabilir durumda olanlar aktivasyona yönlendirilebilecektir.

Sosyal Yardım-sosyal hizmet koordinasyonunun sağlanması asgari gelir desteği alanların sosyal hizmetlerle de desteklenmesini sağlayacaktır. Sosyal hizmet bir anlamda sosyal yardımı destekleyici bir etkiye sahiptir. Diğer taraftan asgari gelir desteğinin Türkiye ekonomisinde itici bir güç oluşturması da mümkün olabilecektir. Bu bağlamda asgari gelir desteği ekonomide yatırım-istihdam-talep döngüsü içerisinde talebi canlandırabilecektir. Asgari gelir desteği ile ellerine belli bir para geçen insanlar satın almaya yönelecekler ve talep canlanacaktır. Talebin canlanması yatırım ve üretime olumlu tesir edecek ve sonuç olarak istihdam artışı gerçekleşecektir. Söz konusu iktisadi boyut çok önemlidir çünkü güçlü bir ekonominin, asgari gelir desteğinin finansmanından aktivasyona kadar bir dizi konuda olumlu etkisi ve katkısı olabilir. Ayrıca iktisadi yapının yanı sıra bölüşüm, yeniden dağıtma mekanizmaları ve vergi politikaları da bu yapıyı destekleyici ve tamamlayıcı rol oynamaktadır. 
26 Haziran 2014 Tarihinde ASPB yetkilileri ile yapılan derinlemesine mülakatta sosyal yardım-istihdam bağlantısı ile ilgili olarak Bakanlığın somut çalışmalarından söz edilmiştir. Örneğin; Bakanlık bünyesinde, evde bakım aylığı alan kişilerin sigorta primlerinin devlet tarafından ödenmesi ve Genel Sağlık Sigortası kapsamına alınmaları ile ilgili çalışmalar yapıldığı konu edilmiştir. Genellikle uzun süreçli olan bu bakım işleri esnasında kişinin başka bir işte çalışması mümkün olmadığından ve bakım sona erdiğinde kişi hem işsiz hem de sigortasız kalacağından Bakanlığın söz konusu projesi büyük önem arz etmektedir. Böyle bir uygulama hayata geçirildiği takdirde evde bakım aylığı, bir tür asgari gelir desteğine dönüşecek, aynı zamanda topluma yararlı bir faaliyet gerçekleşmiş olacaktır.

Görüşülen diğer bir konu İş-Kur ile ASPB arasında daha sıkı bir işbirliğine ihtiyaç duyulmasıdır. Örneğin mevcut uygulamada devlet, İş-kur'un işe yerleştirilmesine aracılık ettiği kişilerden \%5 pirim kesintisi yapmaktadır, benzer şekilde SYGM-İş-kur kanalıyla gerçekleşen işe yerleştirmeler için de pirim kesintisi yapılabilir, ayrıca yüzde miktarının fazla olması teşvik edici olabilecektir. SYGM'den İş-kur’a yapılan yönlendirmelere ve bu şekilde yapılan işe yerleştirmelere devletin farklı avantajlar sunması da mümkündür. Diğer taraftan İş-Kur, bilişim sisteminin bir özelliği olarak "kendi kendine öğrenen sistemler (machine learning system)"i kullanmak suretiyle, geçmiş işe yerleştirmelerle ilgili verilerden otomatik olarak yeni iş başvurusu yapan kişinin hangi işe yerleştirilebileceğine karar verebilir ve bu şekilde doğru kişilerin doğru işlere daha kolay ve hızlı bir şekilde ulaşabilmesi sağlanabilir. ASPB Yetkilileri ile yapılan mülakatta "kendi kendine öğrenen sistem" uygulamada kullanıldığı takdirde, ASPB tarafından İş-kư’a yönlendirilen kişi işi belli sürede kabul etmezse kişinin yardım katsayısının düşürebileceği ifade edilmiştir. Yetkililer tarafından ayrıca, bu uygulamanın bir taraftan istihdama teşvik edici diğer taraftan sosyal yardım açısından cezalandırıcı bir yöntem olacağı ifade edilmekle birlikte asgari gelir desteği uygulamasının daha başlangıcında bu tip bir cezalandırma gerekli olmayabilir, uygulama gözlenmek suretiyle sonraki yıllarda ihtiyaç görüldüğü takdirde katsayıyı düşürme uygulamasının devreye sokulması daha makul ve esnek bir uygulama olacaktır.

\section{Sonuç}

Günümüzde dünyanın her tarafında yaşanan küreselleşme ve neoliberal politikaların etkisiyle sosyo-ekonomik alanda büyük bir dönüşüm yaşanmaktadır. Bu dönüşüm milyonlarca insanı etkilemekte ve yoksulluk, işsizlik, sosyal dışlanma gibi sorunların ortaya çıkmasına yol açmaktadır. Buna karşılık, yaşanan bu sorunlar nüfusun demografik yapısında önemli bir değişime yol açtığı gibi aynı zamanda refah devleti politikalarını da olumsuz yönde etkileyerek sosyal güvenlik sistemlerinin köklü bir kriz yaşamasına da neden olmaktadır. Bütün bu gelişmeler ülkeleri çözüm için yeni arayışlara yöneltmekte ve çözüm için başvurulan çarelerden biri de sosyal yardım politikalarının bir bileşeni olarak asgari gelir desteği uygulaması olmaktadır. Bu çerçevede istihdam odaklı asgari gelir desteği sistemini konu alan bu çalışmada temel olarak "asgari gelir desteği" ve "aktivasyon" konuları incelenerek, sistemin, $\mathrm{AB}$ ülkelerindeki uygulamalar ve sosyal yardım alanındaki mevcut birikim ışığında Türkiye için uygulanabilirliği tartışılmıştır.

$\mathrm{AB}$ ülkelerinde asgari gelir desteği uygulamaları incelendiğinde hem eski olması ve hem de kapsamı itibariyle geniş olması sebebiyle ülkemiz ve diğer gelişmekte olan ülkeler açısından örnek teşkil edebileceği görülmektedir. Avrupa Konseyi, üye devletlerden yasal olarak, ikamet eden herkese, gelir testine tabi tutulmak suretiyle verilen, çalışmaya uygunluğa bağlı, süresiz ve faydalanıcıların tam sosyo-ekonomik entegrasyonunu sağlamaya yönelik, onurlu 
bir yaşam için gerekli kaynak ve hizmetleri alma hakkını temin etmelerini istemiştir. Avrupa Sosyal Şartı'nda ise sosyal dışlanma ve yoksulluğa karşı etkili bir korumanın gerçekleşmesi için, tarafların, gerekli önlemleri, yardıma ihtiyaç duyan veya risk altında yaşayan kişileri ve aileleri kapsayacak ve kişilerin bu önlemlere etkin bir biçimde erişimlerini sağlayacak bir şekilde almaları gerektiği belirtilmektedir. Yukarıda sadece birkaçı ifade edilen ilgili direktifler doğrultusunda Birlik üyesi tüm ülkeler az kapsamlı veya geniş kapsamlı olmak üzere kendi ülke şartlarına uygun bir asgari gelir planı inşa etmişlerdir.

Türkiye'de ise henüz uygulamada olan bir asgari gelir desteği programı mevcut değildir. Bununla birlikte ASPB’nin asgari gelir desteği ile ilgili yaptığı çalışmalardan ve mevcut asgari gelir desteği benzeri uygulamalardan söz edilebilir. ASPB'nin bu konuda ciddi projeleri ve önerileri bulunmaktadır. Türkiyede uygulanan yardım programları içerisinde asgari gelir desteğine benzeyen ve kişiye geçimini sağlamak üzere düzenli olarak verilen hak niteliğindeki yardımlar, 2022 Sayılı Kanun gereği çalışacak durumda olmayan yaşlılara ve özürlülere verilen yardımlardır. Kişiler SGK tarafından yürütülen bu özürlü ve yaşlı aylıklarından muhtaçlık durumları devam ettiği müddetçe yararlanabilmektedirler. Ayrıca çocuklara ve gençlere yönelik düzenli niteliği olan sosyal yardım programları da mevcuttur. Bu yardımlar çocukların ve gençlerin geçimini temin etmek üzere kurgulanmamıştır. Yardımların amacı çocukların sağlık kontrollerinin yapılması (şartlı sağlık yardımları) ve çocukların ve gençlerin eğitime devamlılıklarını (şartlı eğitim yardımları) sağlamaktır ve ancak bu şartlar yerine getirildiği takdirde yardıma hak kazanılmaktadır. Söz konusu yardımlar düzenli nitelikte olmaları sebebiyle asgari gelir desteğine benzemekle birlikte, kişinin geçimini sağlamaya yönelik olmadığı için daha farklı bir yapıdadır. Sağlık yardımları ayni nitelikte olup kişinin sağlık kontrolüne ihtiyaç duyması halinde sağlık masraflarının karşılanması suretiyle gerçekleştirilmektedir, amacı itibariyle ve nakit transferi olmaması sebebiyle asgari gelir desteğinden farklılaşmaktadır. Benzer şekilde ihtiyaç sahibi kimselere yönelik diğer sosyal yardım programları da arızi durumlarda düzensiz olarak yapıldıkları için asgari gelir desteğinden farklı bir yapıdadırlar. SYDV'lerin verdiği periyodik nakit yardımları da asgari gelir desteğine benzer uygulamalardır. Ancak bu yardımlar "hak temelli" olmadığından devamlılığı konusunda bir garanti bulunmamaktadır. SYDV yardımları istediği zaman kesebilmektedir.

Ülkemizde gelir dağılımı eşitsizliği, göç, sosyal güvenlik sisteminden kaynaklanan sorunlar, işsizlik, kayıtdışı istihdam, eğitim sisteminin işgücü piyasasının isteklerine ve gereklerine cevap verememesi, ekonomik krizler gibi birçok faktör yoksulluk üzerinde etkilidir, bu sebeple yoksullukla mücadelenin çok yönlü olarak yürütülmesi gerekmektedir. Makro seviyede düşünüldügünde yapılması gerekenler; güçlü ve sürdürülebilir bir ekonomik büyümenin sağlanması, adaletli bir gelir paylaşımı ve toplumun tamamını kapsayan bir sosyal güvenlik sisteminin inşasıdır. Ekonomik büyümenin yoksullukla mücadeleye olumlu katkısı ancak sosyal koruma ile birlikte yeterli gelir getirecek istihdam alanlarının yaratılması ile mümkündür. ILO bu noktada düzgün iş kavramının önemine ve istihdam, gelir ve sosyal korumanın çalışanların haklarından ve standartlarından ödün verilmeden yapılması gerektiğine vurgu yapmaktadır. 


\section{Kaynakça}

Aile ve Sosyal Politikalar Bakanlığı Sosyal Yardımlar Genel Müdürlüğü, 2012 Sosyal Yardım İstatistikleri Bülteni, Ankara, 2012.

Alper, Yusuf ve Arabacı, Rabihan Yüksel, "Yoksullukla Mücadele, Vatandaşlık Geliri ve Aile Ödenekleri Sigortası,” Türk-Işs Dergisi, 389, 2010.

Buğra, Ayşe, Keyder, Çağlar ve Erdem, Ilgın. "Sosyal Yardım Uygulamaları ve Topluma Yararlı Faaliyet Karşılığında Asgari Gelir Desteği Uygulaması”, Ankara: UNDP, 2006, (Çevrimiçi) http://www.undp.org.tr/publicationsDocuments/socialassistancereports. pdf (02.01.2012).

Casas, Ramón Peña, "Minimum Income Standards in Enlarged EU: Guaranteed Minimum Income Schemes" Working Paper II: Setting Minimum Social Standards across Europe, (Çevrimiçi) http://www.eapn.ie/pdfs/155_paper\%20II\%20-\%20Minimum\%20income \%20standards\%20in\%20enlarged\%20EU.pdf (12.04.2012).

Coşkun, Selim, Güneş, Samet ve Ortakaya, Fatih, "Asgari Gelir Desteği ve Türkiye’de Uygulanabilirliği: Bir Model Denemesi,” Gazi Üniversitesi İ.I.B.F. Dergisi, 13/3, 2011.

Crepaldi, Chiara, Gambino, Alfonso, Baldi, Simona, Da Roit, Barbara ve Ortigosap, Emanuele Ranci, "The Role of Minimum Income for Social Inclusion in the European Union 2007-2010", Report Made for European Parliament, Milan, 2010.

Çalışma ve Sosyal Güvenlik Bakanlığı, Çalışma Hayatı İstatistikleri 2011, Ankara, 2012.

EuropeAid, “Asgari Gelir Programları Hakkında Ek Rapor,” (Çevrimiçi) http://www.sgkkap.org/database/reports/B1_C5_006.pdf (12.01.2012).

Gürses, Didem, “Türkiye'de Yoksulluk ve Yoksullukla Mücadele Politikaları”, Balıkesir Üniversitesi Sosyal Bilimler Dergisi, 17/1, 2007.

Karakoyun, Erdal ve Erdal, Fuat, "Şartlı Nakit Transferleri ve Çocuk Yoksulluğu ile Mücadele: Sosyal Riski Azaltma Projesi (SRAP) Şartlı Nakit Transferi (ŞNT) Bileşeni: Aydın İli Uygulaması", Finans, Politik ve Ekonomik Yorumlar, 46/529, 2009.

Madenoğlu, Kemal, "Yoksullukla Mücadelede Asgari Gelir Desteği Türkiyedeki Uygulama”, Türk-İş Dergisi, 389, 2010.

Negiz, Nilüfer, "Sosyal Yardım ve Sosyal Hizmet Faaliyetleri Açısından Isparta Belediyesi: Farkındalık, Yararlanma ve Değerlendirme Açısından Bir Araştırma”, Süleyman Demirel Üniversitesi İktisadi ve İdari Bilimler Fakültesi Dergisi, 16/2, 2011.

Önen, S. Mustafa, "Yerel Yönetimlerin Yoksullukla Mücadelesi: Malatya Belediyesi Örneği”, Sayıştay Dergisi, 79, 2010.

Özürlü ve Yaşlı Hizmetleri Genel Müdürlüğü, Ankara: Yaşlanma Ulusal Eylem Planı Uygulama Programı Taslağı, 2012.

Şener, Ülker, "Yoksullukla Mücadelede Sosyal Güvenlik, Sosyal Yardım Mekanizmaları ve İş Gücü Politikaları", TEPAV Politika Notu, Şubat 2010.

Taş̧̧ı, Faruk, Sosyal Politikalarda Can Simidi Sosyal Yardım, Ankara: Nobel Yayın Dağıtım, 2010.

Zabcı, Filiz Çulha, "Sosyal Riski Azaltma Projesi: Yoksulluğu Azaltmak mı, Zengini Yoksuldan Korumak mı?”, Ankara Üniversitesi SBF Dergisi, 58/1, 2003. 
İNSAN\&İNSAN, Sayı 3, Kış 2015

ISSN: 2148-7537, www.insanveinsan.org

Seeking the Employment Focused Minimum Income Support for Turkey in the Framework of European Union Applications

İLKNUR KARAASLAN

Abstract: The economic crises realized along with the globalization process have led to an increase in the problems such as poverty, unemployment, social-exclusion. The heavy socioeconomic conditions have also led to a long-established crisis on the social security systems and "minimum income support" has become one of the referenced methods as solution. When looking at the minimum income support practices in EU countries, as they were both, old and comprehensive it has been thought that they could be exemplary to our country. On the other hand, the EU countries have been in difficulties to separate allowance for the social assistance applications and therefore, especially from the beginning of the 2000s, EU countries have given an importance to the activation (the activities leading the social assistance beneficiaries to the employment) policies.

"Minimum income support" applications do not exist in Turkey, however there are "similar" applications. On the other hand, it has been thought that as in the case of EU applications also in Turkey, the social transfers and specifically the "a minimum income" support might be effective in reducing poverty and as similar to EU applications minimum income support should be given with the condition of activation in Turkey.

Keywords: Minimum income support, European Union, employment. 